\title{
The Role of Socio-Culture and the Factors Affecting the Development of the Baduy Community
}

\author{
Sumawijaya ${ }^{1}$, I Nyoman Sumaryadi ${ }^{2}$, Erliana Hasan ${ }^{3}$, Sampara Lukman $^{4}$ \\ 1,2,3,4 Institut Pemerintahan Dalam Negeri (IPDN), Indonesia \\ Email: sumawijaya1002@gmail.com
}

\begin{abstract}
The Baduy tribe is one of the tribes located in Lebak Regency, Banten Province. The Baduy tribe firmly adhere to the customs and culture of their ancestors. The Baduy tribe is very closed because they carry out the mandate outlined by their ancestors, namely in the form of a simple lifestyle, away from modern cultural influences and presenting themselves in the way of life carried out by their ancestors without changing it. The consequence of this makes the Baduy tribe very little touched by the progress and rapid development. This study aims to analyze the socio-cultural role in improving the development of the Baduy people and the factors that support and hinder the Baduy community's development. This study used a qualitative approach, using descriptive methods to analyze the collected data. The results showed that association with the outside world made the Baduy people come into contact with modern technology, which for hundreds of years so that many social changes occurred in the Baduy community. The research also found factors that encourage and hinder the development of the Baduy community, including contact with other cultures, open community systems, community dissatisfaction, lack of relationships with other communities, late development of knowledge, and entrenched customs.
\end{abstract}

Keywords: Socio-Culture, Development, Indigenous Peoples.

\section{A. INTRODUCTION}

Indonesian society has long been known to be very heterogeneous in various aspects, such as the diversity of ethnic groups, religions, languages, customs, and so on (Raharjo, 2010). On the other hand, the rapid development of the world today with very high mobility and dynamics has led the world towards a "world village" with almost no boundaries due to the development of modern technology (Lochtman \& Kappel, 2008). Therefore, society (in a broad sense) must be ready to face new situations in the context of cultural diversity or whatever it is called. Interaction and communication must also run with one another, do you already know each other or have never met at all, let alone know each other (Mcluhan \& Powers, 1989).

Culture is everything related to mind and reason, and everything is produced by reason and sense (Koentjaraningrat, 1974). Culture is something complex that reflects every meaning and tradition that exists in a society. According to EB Tylor, culture is a complex whole, which contains other knowledge and habits that humans acquire as members of the community (Hofstede, 1980). Culture is a set of values, beliefs, and traditions acquired or learned, accepted by society. From generation to generation as a unit that helps direct its members (Surya, 2009). 
Culture is a habit that has been carried out from generation to generation and is accepted as an applicable norm as a guide for society to behave to achieve its goals (Eliot, 2010). This culture's role dramatically affects the shape of the state of a community if the culture that is owned has a role in untangling the tangled threads of poverty; for example, through its social institutions, it can automatically contribute to poverty (Small et al., 2010). Conversely, if culture with existing values is maintained without regard to the ability of the community and its relevance in its development, it needs to be adjusted to the conditions experienced by the household, then culture contributes to the creation of the household situation culturally (Hill, 2002).

Culture is an essential character of a social environment that distinguishes it from different cultural groups. A cultural factor is a society's habit of responding to things that are considered to have values and traditions, which can be started from them receiving information, their social position in society, and knowledge-they about what they feel (Golding \& Baezconde-Garbanati, 1990). Culture is a fundamental determinant of a person's desires and behavior. Socio-culture can also be interpreted as social values accepted by society as a whole and spread to its members through language and symbols (Nesse, 2010).

As a socio-cultural element, society's view about its relationship with nature needs a proper understanding because it has a connection with a lifestyle. Experts say there are three types of opinions on this matter: humans control nature, humans are controlled by nature, and humans must maintain a harmonious relationship with nature (Indrawardana, 2012).

If a society adheres to the view that humans control nature, what often happens is that all the wealth contained therein is exploited and utilized for the enjoyment of human life. Communities that adhere to this concept are often seized by the "disease" of materialism and hedonism because, among other things, place gains and control more and more-much wealth as a measure of one's success. The community members said, "enjoy today and let tomorrow take care of itself."

People who believe that humans are controlled by nature argue that the earth is only a microcosm and is part of the macrocosm, namely the universe with everything in it. In that society, the philosophy of "predeterminism" usually extends from the view of the existence of an almighty power that controls the universe. The religious people call it "Almighty God," and humans must completely obey that power.

The third view is that humans must maintain a harmonious relationship with nature, which can be an amalgamation of the main ideas in the first and second views mentioned above. This means that even though humans may take advantage of nature and the various wealth contained therein for humanity's welfare, nature should not be destroyed in that use. Even a view says that if humans cannot maintain a harmonious relationship with nature and destroy it, the character has its way of "revenge" (Indrawarna, 2012). 
Baduy is one of the ethnic names among several ethnic groups in Indonesia. This community group is known to be closed lives in the Kendeng mountains, which administratively is part of the Kanekes Village area, Leuwidamar District, Lebak Regency, Banten Province.

The Baduy tribe is not isolated, but a tribe that deliberately isolates itself (closes itself) to carry out the Buyut Mandate or pikukuh, namely the mandate outlined by the ancestors. The deeply embedded ancestral heritage is a simple lifestyle, away from the influences of modern culture, representing oneself in the way of life used by the ancestors without changing it (Maharani, 2009). The consequence of being a tribe that closes itself requires that they can provide all the necessities of life, both clothing, food, and shelter, from the potential of their natural resources. Besides, they build a socio-cultural system that regulates life in groups, including rules containing obligations, accepted and rejected actions, prohibited activities, stories that are permitted, and certain binding sanctions on every deviant act (Mustomi, 2017).

The uniqueness of the Baduy tradition is built from persistence and loyalty in carrying out the ancestral mandate, in which the values of simplicity, honesty, wisdom in maintaining harmony in the universe, the ability to maintain the authenticity of tradition by closing oneself from external cultural influences (modernity) are a phenomenon connected to Another phenomenon, namely the ability to trade, where the profession requires interaction with the outside world and good communication skills.

The Baduy tribe's persistence in maintaining and defending the principles of life is guided by the "Buyut's Mandate" or the mandate inherited from their ancestors. The mandate of the great-grandfather is a source of value from the Baduy socio-cultural system. As a source of value, ancestral mandates function as a philosophy of life passed down from generation to generation, maintained and maintained amid modern life as it is today. This principle is strongly reflected in the attitudes and actions taken in everyday life (Suparmini et al., 2013).

Baduy is classified into two major groups: Inner Baduy (tangtu), and Outer Baduy (panamping), where the classification shows a different representation of traditional patterns between the two. The first group, called the Inner Baduy Tribe or tangtu, represents the past Baduy Tribe. The group shows this with a powerful tendency in carrying out the ancestral mandate; they bind themselves firmly to the traditional rules outlined by the ancestors. The Inner Baduy community is strictly prohibited from owning and using electronic goods, eating and drinking utensils made of glass, plastic. The house must not use nails, only use pegs and rattan ropes, and only have one door. They are prohibited from attending school, using footwear, driving, and so on. This group occupies the Ciekeusik, Cikartawana, and Cibeo areas.

While the second group is the Outer Baduy or Panamping, their traditional life patterns are starting to loosen and open up. They have adopted many foreign cultural practices. They are used to driving as a means of transportation, using cell 
phones to communicate, and so on. The Baduy tribe is what we often see with their distinctive clothing characteristics offering traditional merchandise in various places, even to big cities like Jakarta. This condition shows that the Outer Baduy have an excellent trading spirit; they sell merchandise in the form of natural products, handicrafts, medicines, even objects that are said to have magical powers.

In this study, the authors will try to analyze the socio-cultural role in enhancing the development of the Baduy community and the factors that influence this development due to the Baduy tribe's nature, which is very closed and highly upholds the customs and heritage of their ancestors.

\section{B. METHOD}

This study uses a qualitative method. Qualitative research starts from the view that the focus of research is the quality of essence and essence. McMillan \& Schumacher in Syamsuddin states that qualitative research is an approach which is also called an investigative approach because researchers usually collect directly and interact with people at the research site. With this qualitative approach, the researcher will describe and analyze each individual in his life and thoughts. Researchers who use this approach must interpret all phenomena and objectives through an explanation (Syamsuddin \& Vismaia, 2009).

Judging from this research, it is appropriate to use a qualitative approach because the research problem being studied requires continuous review. This research requires a comprehensive, complete, total, in-depth, focused, and in-depth study. Qualitative research, according to Sukmadinata: qualitative research is aimed at understanding social phenomena from the participants' perspective. Participants are invited to be interviewed, observed, and asked to provide data (Sukmadinata, 2011).

\section{RESULT AND DISCUSSION}

\section{The Role of Socio-Culture in Improving Baduy Community Development}

Like in general, people who are still very close to their family ties, in everyday life interact with each other. Both with neighbors whose houses are close to each other and with residents outside their village. The interaction process always produces something that might change the habits or thought patterns they have previously held. Most of the Baduy people themselves are used to interacting with people outside Baduy with increasing tourist visits or from the Baduy community themselves who travel to the city (Ahidin et al., 2018).

a. Inner Baduy and Outer Baduy Communication

Every regulation in Outer Baduy is not much different from Inner Baduy because the people in Outer Baduy are still very dependent on every rule made by the government in Inner Baduy. For example, when there is a violation committed by the Outer Baduy community, the village Kakolot, and the RT head who handle it, the punishment will be imposed on the violator according to the rules that are enforced and made according to Inner Baduy custom. Likewise, when there are 
certain customary celebrations or rituals, Inner Baduy and Outer Baduy both carry out traditional rituals simultaneously.

Officers from Inner Baduy often toured every village in Outer Baduy and did the Outer Baduy people keep any items prohibited by custom or just joking with the Outer Baduy community. In essence, they are both Baduy people; they must protect their homeland.

b. Outer Baduy Community

Like most people who live side by side with each other, the people in Outer Baduy too. They are divided into 55 villages which are close to each other from one village to the next. In each village, there is an RT head, the RT Head, who manages each of its residents. The daily lives of the Outer Baduy community are almost the same, men farming and women weaving cloth at home. They can peddle their handicrafts in front of the house. The goods they sell are not always hand-made to be sold to tourists. They live very harmoniously and peacefully, maintaining peace together. This can also be seen when in Cibeo Village, several Outer Baduy people are selling in Cibeo Village, Inner Baduy.

c. Communities with Communities outside Baduy

When entering the Baduy area, there are several stalls for instant food, vegetables, or salted fish; they also sell handicrafts that come from within the Baduy village. Not a few of the men work as tour guides and porters (goods carrier services) for visitors who want to be accompanied. Many Outer Baduy people leave the village for several purposes, including buying daily necessities, working, or just visiting. Even though people outside the Baduy tribe live side by side with different cultures and customs, they still respect and protect each other. The people outside Baduy understand the rules that are strictly guarded by the customs of the Baduy people. They also understand a little about Baduy culture. The people in Outer Baduy are immensely helped by the interactions that exist with people outside the Baduy tribe.

\section{Baduy Social Change}

a. How to dress

The Baduy community, which was initially discovered by researchers from the Netherlands, is a group of relatively closed off foreigners outside Baduy. However, nowadays, Baduy is well known as a cultural tourism destination in Indonesia, making interactions between Baduy people turn dynamic. This interaction will have a significant impact on the Baduy community, one of which is the dress code. The following are the changes in the dress code of the Baduy or Urang Kanekes people:

The Outer Baduy community is experiencing rapid social growth because it has quite loose customary rules than Inner Baduy. For how to dress in the early days, the Outer Baduy people wore distinctive clothes, namely, with all black clothes and blue headbands. However, based on observations, the author sees that currently, most of the Outer Baduy people no longer wear their typical clothes, 
namely all black clothes and black headbands. They already wear clothes like people outside Baduy in general, and Outer Baduy people wear footwear. In terms of dress code, the Outer Baduy people have experienced social changes due to intensive interaction with tourist visitors. This can be seen from the way the Outer Baduy people wear clothes in general.

The Inner Baduy community still applies a fairly strict customary system and must obey all of its people. For the dress code rules, the Inner Baduy community is required to wear clothes with a characteristic white natural color and a white headband. From the observations of the author while in Inner Baduy, precisely in Cibeo Village, it can be seen that all Inner Baduy people still wear their distinctive clothes, namely with white garments and white headbands, and the people do not wear footwear or can be said even to follow customary rules. In terms of dress procedures, Baduy residents still obey customary regulations. There is no impact on social change from tourist visitors' interactions to the residents of Cibeo village.

b. Application and Knowledge of Technology

The rules of the Outer Baduy community are not much different from the laws of the Inner Baduy community. However, it is only different from its implementation; the Outer Baduy community is given leeway in implementing it. In the application and knowledge of technology in the Outer Baduy community, it has become commonplace. However, sometimes if there is a sudden search by the local Inner Baduy and Jaro people, the object will be seized and given a warning. Technological devices or cellphones have become standard items used by the Outer Baduy community. Even when we were staying in one of the Outer Baduy villages, there was one house that already had access to electricity and had lights installed. However, when we arrived, the lights were not turned on. The use of electricity is strictly prohibited by the customary government itself, even for Outer Baduy.

c. Use of Language

During collecting interviews and observation data in Baduy, using the language was a bit constrained because some Baduy people did not speak Indonesian well. However, not many Baduy people are already fluent in using Indonesian well. For the use of the language itself, there is a difference in the proportion between Outer and Inner Baduy.

In the Outer Baduy area, or to be precise in the Kaduketuk village, which is located very close to the Ciboleger terminal, many residents can speak Indonesian correctly and adequately. However, when they arrived at the place to spend the night or, to be precise in the village of Kaduketer, some of the residents were relatively closed and were not fluent in using Indonesian. When arriving in this village, visitors are better off using Sundanese to facilitate communication because if visitors insist on using Indonesian, it will complicate the communication process.

\section{Factors Affecting the Development of the Baduy Community}

The social changes that occur in every society come from within the community and culture itself. These changes occur due to population numbers, 
natural environment, and physical changes in the place where they live. Social change cannot be separated from the consequences of social interaction of society itself on both modern and primitive cultures.

Social change in primitive societies is included in evolution because it is a form of social change that takes place slowly, with the condition of the society having a tough character and having difficulty accepting new cultures and leaving their local customs. So that this can hinder social change because it is difficult for new cultures to enter the community.

Inner Baduy does not recognize written culture, so customs, beliefs/religions, and ancestors' stories are only stored in oral speech. The Baduy community does not know schools because formal education is against their customs. Even today, the government's attempts to change a life by building modern school facilities in their area since the Soeharto era are rejected. As a result, the majority of Baduy people cannot read and write.

The Kanekes community, which until now strictly adheres to customs, is not an isolated, remote, or isolated community from the development of the outside world. The establishment of the Sultanate of Banten, which automatically included Kanekes into its territory, could not be separated from their awareness. As a sign of obedience/recognition to the authorities, the Kanekes community routinely carried out Seba to the Sultanate of Banten (Garna, 1993). Until now, the seba ceremony has been held once a year, in the form of delivering crops (rice, crops, fruits) to the Governor of Banten (previously to the Governor of West Java), through the regent of Lebak Regency (Rusnandar, 2013).

In the agricultural sector, the Kanekes Luar residents interact closely with the outside community to rent land and laborers. Trades that were previously carried out by barter are now using the ordinary rupiah currency. The Kanekes sell their fruits, honey, and kawung / palm sugar through intermediaries. They also buy necessities of life that are not produced in the market themselves. Markets for the Kanekes people are located outside the Kanekes area, such as Kroya, Cibengkung, and Ciboleger markets.

At this time, the number of outsiders visiting the Kanekes area increased to hundreds of people per visit, usually teenagers from schools, students, and other adult visitors. They accept these visitors, even for a one-night stay, provided that the visitor obeys the prevailing customs there. These customary rules include not taking pictures in the Kanekes Dalam area, not using soap or toothpaste in the river.

However, the Kanekes area remains off-limits to foreigners (non-Indonesian citizens). Several foreign journalists who have tried to enter until now have always been denied entry. When the work in the fields was not too much, the Kanekes also liked to travel to the big cities around their area on the condition that they had to walk. In general, they go in small groups of 3 to 5 people, visit the homes of acquaintances who have been to Kanekes while selling honey and handicrafts. During these visits, they usually get additional money to make ends meet. 
In terms of food, the Baduy people are very fanatical. They don't want to eat anything other than the traditional food they eat every day. Understandably, the people who live in the interior of the Kendeng Mountains, Kanekes Village, Leuwidamar District, Lebak Regency, Banten, really adhere to their ancestors' customs to this day.

They will not eat the kind of food their ancestors did not eat. They also will not make habits that their ancestors never did before. The tradition of bathing without using soap is still ongoing today.

Not using soap does not mean they have no money, but actually for the sake of following their parents' habits. If there are Baduy residents who try to use soap while bathing and get caught, they will receive a harsh warning. This warning could lead to dismissal as a resident of Inner Baduy.

The Baduy people live by strict customary rules. In Inner Baduy, pikukuh or customary rules are non-negotiable prices. This is different from Outer Baduy, which still allows vehicles to ride. Despite seeing the various technological goods brought by tourists, the Inner Baduy people still maintain their customs. They are still "faithful" walking, prioritizing honesty, refusing to pollute the environment (land and water), and not smoking. The Inner Baduy applies adat more strictly than the Outer Baduy.

Daily Baduy people speak Sundanese harshly. The language they use does not recognize the level of language or language usage based on social status. Respect for others is not shown through unique words but their behavior. Adat requires them to speak Sundanese to maintain the purity of the community's culture. However, it is not difficult to find Baduy people who can speak Indonesian, especially in Outer Baduy. Those who are fluent in Indonesian are usually people who frequently travel to cities.

The social changes that occur in the Baduy community include evolutionary changes. Evolutionary changes are social changes that happen in a slow process, for a long time and without any particular will from the society concerned. These changes occur following the conditions of community development, namely in line with the community's efforts to meet their daily needs. In other words, social change occurs because of the encouragement of people's efforts to adapt themselves to their needs with the development of society at a particular time.

In social change, there are driving and inhibiting factors and social growth in the Baduy community. The inhibiting factors for social change in the Baduy community are as follows:

a. Lack of Relationship with Other Communities. Before there were foreign tourists who knew Bedouins' existence, their life was every day without disturbing social changes. Because they only live by relying on the rules of their parents. The alienated life of the Bedouin community made them not aware of developments that had occurred. This causes the patterns of thinking and experience of the Bedouins to become static. 
b. Late Development of Science. This can be due to isolated and closed people's lives; even they are prohibited from watching TV as described above. So they get very little information and knowledge. The Community's Attitude is Still Very Traditional In Bedouin society, some elders still like to glorify traditions. The past can make them complacent and challenging to accept the progress and changes of the times. However, it is somewhat different from the young Bedouin people; they are more or less contaminated with outside cultures.

c. They are rooted in Customs or Habits. Customs or habits are patterns of behavior for community members in meeting their daily needs. Sometimes customs and traditions are so strong that they are difficult to change. This is an obstacle to cultural development and change. As happened in the story above. In terms of food, the Baduy people are very fanatical. They don't want to eat anything other than the traditional food they eat every day. Understandably, the people who live in the interior of the Kendeng Mountains, Kanekes Village, Leuwidamar District, Lebak Regency, Banten, really adhere to their ancestors' customs to this day. At present, due to globalization, there are changes in Bedouin society little by little.

While the driving factors for social change in the Baduy community are as follows:

a. There is contact with other cultures. These changes occur due to people's efforts to adapt to environmental conditions and new conditions that arise in line with community growth. This is following the Baduy people's condition who live in the interior of the forest and are still isolated so that outside culture has not entered. Besides, the inner Baduy people are the most obedient to all the rules and regulations that have been established by the $P u^{\prime}$ un (Customary chief). However, over time, many tourists, both domestic and foreign, visit the Bedouins with various influences from the Baduy customs. Even so, change can occur without breaking the pikukuh, because indeed the action is desired or a compelling situation so that the shift occurs outside their will so that tolerance arises from the traditional leaders towards it.

b. Open Community System (Open Stratification). The current Bedouin community is much more open and more friendly than the previous Bedouin community, making it easier for them to accept the new culture even though it is strictly forbidden by their elders / pu'un. As revealed in the story above, apart from speaking Indonesian, some Inner Baduy people can also use Betawi dialect words and even extract English vocabulary.

c. Public Dissatisfaction with Certain Areas. Intercourse with the outside world brings the Baduy community into contact with modern technology, which has been prohibited by custom for hundreds of years. Like other societies, they currently watch television, use watches, and even own a radio. They inevitably think about being able to follow current trends and show that they 
also feel less satisfied with the technology they have so far. They want to have more knowledge by watching tv or listening to the radio.

\section{CONCLUSION}

Intercourse with the outside world brings the Baduy community into contact with modern technology, which has been prohibited by custom for hundreds of years. Along with the times, there have been many social changes in the Inner Baduy community. Social changes in Baduy society include the Theory of Evolution (Evilution Theory) because this theory is based on changes that require a relatively long process. Supporting factors that influence the development of the Baduy tribe include (1) Contact with other cultures, (2) Open System of Inner Baduy (Open Stratification), (3) Public dissatisfaction with specific fields: Intercourse with the outside world makes Baduy people come into contact with modern technology that custom has forbidden for hundreds of years. Like other societies, they currently watch television, use watches, and even own a radio. They inevitably think about being able to follow current trends and show that they also feel less satisfied with the technology they have so far. Inhibiting Factors for Social Change (1) Lack of relationship with other communities. (2) Late development of science, (3) Community attitudes that are still very traditional and entrenched customs.

Local wisdom in the form of knowledge, beliefs, understanding, insight, and customs or ethics that guide human behavior in life is closely related to the conditions of the region and community that are passed down from generation to generation so that the form of local wisdom can be seen through a cultural approach, which consists of local knowledge. , local culture, local skills, local resources, and local social processes. Local wisdom of the Baduy community in conservation and environmental preservation efforts will include three elements, namely social (harmonious), economic (profitable), and ecological (sustainable). The three aspects of sustainable environmental management and preservation show that they are connected. Wisdom plays a role in maintaining the three functions of sustainability.

\section{REFERENCES}

1. Ahidin, U., Handayani, R., \& Suraya, A. (2018). Penyuluhan Manajemen Informasi Dengan Mempertahankan Kehidupan Sosial Budaya Masyarakat Suku Baduy. Jurnal Pengabdian Dharma Laksana, 1(1), 1-10.

2. Eliot, T. S. (2010). Notes towards the Definition of Culture. Faber \& Faber.

3. Garna, J. (1993). Masyarakat Baduy di Banten. Masyarakat terasing di Indonesia, 120-152.

4. Golding, J. M., \& Baezconde-Garbanati, L. A. (1990). Ethnicity, Culture, And Social Resources. American Journal of Community Psychology, 18(3), 465-486.

5. Hill, R. P. (2002). Consumer Culture and the Culture of Poverty: Implications for Marketingtheory and Practice. Marketing Theory, 2(3), 273-293.

6. Hofstede, G. (1980). Culture and Organizations. International Studies of Management $\mathcal{E}$ Organization, 10(4), 15-41. 
7. Indrawardana, I. (2012). Kearifan Lokal Adat Masyarakat Sunda dalam Hubungan Dengan Lingkungan Alam. Komunitas: International Journal of Indonesian Society And Culture, 4(1).

8. Koentjaraningrat. (1974). Kebudayaan, Mentalitet dan Pembangunan. Jakarta: Gramedia Pustaka Utama.

9. Lochtman, K., \& Kappel, J. (2008). The World A Global Village: Intercultural Competence in English Foreign Language Teaching (Vol. 11). ASP/VUBPRESS/UPA.

10. Maharani, S. D. (2009). Perempuan dalam Kearifan Lokal Suku Baduy. Jurnal Filsafat, 19(3), 199-213

11. McLuhan, M., \& Powers, B. R. (1989). The global village: Transformations in world life and media in the 21st century. Communication and Society.

12. Mustomi, O. (2017). Perubahan Tatanan Budaya Hukum pada Masyarakat Adat Suku Baduy Provinsi Banten. Jurnal Penelitian Hukum De Jure, 17(3), 309-328.

13. Nesse, R. M. (2010). Social Selection And The Origins of Culture. Evolution, culture, and the human mind, 137-50.

14. Rahardjo, M. D. (2010). Merayakan Kemajemukan Kebebasan dan Kebangsaan. Jakarta: Kencana.

15. Rusnandar, N. (2013). Seba: Puncak Ritual Masyarakat Baduy di Kabupaten Lebak Provinsi Banten. Patanjala, 5(1), 82-98.

16. Small, M. L., Harding, D. J., \& Lamont, M. (2010). Reconsidering Culture and Poverty. Special Issue. The ANNALS of the American Academy of Political and Social Science, 629(1): 6-27.

17. Sukmadinata, N. S. (2011). Metode Penelitian dan Pendidikan. Bandung: Remaja Rosdakarya.

18. Suparmini, S., Setyawati, S., \& Sumunar, D. R. S. (2013). Pelestarian Lingkungan Masyarakat Baduy Berbasis Kearifan Lokal. Jurnal Penelitian Humaniora, 18(1).

19. Surya, A. (2009). Studi Deskriptif Potret dan Kehidupan Keluarga Nelayan Tradisional Medan Labuhan. Jurnal Sain, Teknologi, Kesehatan, Sosial, Ekonomi $\mathcal{E}$ Informatika, 2(1).

20. Syamsuddin, A. R., \& Vismaia S. D. (2009). Metode Penelitian Pendidikan Bahasa. Bandung: Remaja Rosdakarya. 